\title{
IDENTIFIKASI KEBUTUHAN PSIKOLOGIS REMAJA DENGAN GANGGUAN DEPRESI DI SURABAYA
}

\author{
Hamidah \\ Marlina S. Mahajudin \\ Fakultas Psikologi Universitas Airlangga Surabaya \\ Email: hamidah_dra@yahoo.com
}

\begin{abstract}
The purpose of this study was to get information about the psychological needs of adolescents with depressive disorders. The information was revealed: 1. the number and levels of depression, 2. Psychological needs, 3. support needs, 4. Close people needed. The method used was survey, with a descriptive analysis. Subjects were 1054 people, which consist of 570 men and 484 women in $2^{\text {nd }}$ grade of State and Private Senior High School in Surabaya. Results of the study that there was $0 \%$ teens that don't have depression and depression in mild, 42 people (4.022\%) were depressed, 917 people (87.8\%) had major depression, 95 people (9.09\%) had acute depression. Acute depression disorders experienced more in female subjects than in males, that is 11, 98\% to 6.49\%. Forms of psychological needs of adolescents with depression is social support such as: information related to depression as much as 10.7\%, emotional support (encouragement, affection, closeness and willingness to listen complaints) $40.8 \%$, financial support (provide facilities to entertain themselves, switch to eat and go to a place of entertainment, refreshment or a walk and exercise) 16.7\%, moral support (advice, discourse, confidence and calmness) as much as $31.8 \%$. Initial action was to lock themselves alone and do reflection as much as 38.6\%; entertaining themselves as much as 15.4\%; having exercise as much as $10.9 \%$; having refreshment $35.1 \%$. Actions to solve issue are sharing with friend as much as $48.7 \%$; sharing with parents as much as $15.4 \%$; silent as much as $30.8 \%$ and others as much as 5.1\%. The expected parenting type is democratic 95\%, authoritarian as much as $1 \%$ and the remaining $4 \%$ is permissive.
\end{abstract}

Key words: adolescents, depression and psychological needs.

Bum (2006) menulis dalam bukunya bahwa depresi adalah penyakit nomer satu penyebab bunuh diri yang dilakukan oleh anak-anak dan remaja, bahkan kondisi ini terjadi di seluruh dunia. Beberapa tahun terakhir ini di Indonesia sedang marak adanya kasus bunuh diri pada anak dan remaja. Data dari Komnas Perlindungan Anak (PA) menunjukkan bahwa dari 20 kasus bunuh diri yang terjadi enam bulan terakhir, $80 \%$ nya dilakukan oleh remaja. Bahkan, pemicu terjadinya perilaku tersebut bukanlah masalah yang berat dalam persepsi umum, namun sangat membebani menurut ukuran individu. Sebagaimana dijelaskan oleh Mulayadi (2006) bahwa kebanyakan stres dan depresi yang dialami oleh anak bersumber dari orang-orang terdekatnya, yaitu orang tua, guru, teman dekat, atau anggota keluarga lainnya. Remaja melakukan bunuh diri dikarenakan adanya tekanan atau depresi yang tidak diketahui bagaimana cara menanganinya, serta tidak ada pihak lain yang peduli dengan kondisi yang dideritanya.

Selain adanya keinginan bunuh diri sebagai akibat dari depresi yang berkepanjangan. Gangguan deprsi adalah gangguan yang menimbulkan perubahan atau penurunan pada bidang kognitif, afektif dan motorik, sehingga gangguan ini akan menimbulkan banyak kerugian bagi penderitanya. Menurut Beck (1967), remaja yang mengalami depresi memunculkan simptom-simptom yang cukup merugikan, baik secara psikologis maupun sosial. 
Adapun simptom psikologis yang muncul adalah adanya perasaan negatif terhadap diri sendiri, menurunnya minat sosial, kehilangan keterikatan dengan orang lain, menangis berkepanjangan, kurang aktif dalam merespon lingkungan, menyalahkan diri sendiri, harapan yang negatif, mengkritik diri sendiri, mempunyai citra diri negatif, menghindar dari akivitas sosial, selera makan rendah, mengalami gangguan tidur, mudah lelah, mengalami halusinasi dan delusi, serta tidak memiliki kemauan untuk bertindak. Apabila kondisi ini dibiarkan dan tidak segera ditangani, maka akan dapat menyebabkan terjadinya gangguan mental secara lebih serius.

Depresi menjadi gejala yang penting diperhatikan, sebab mengganggu kondisi dan kehidupan individu dalam hal motivasi, emosi, kognitif, perilaku, faktor fisik dan biologis (Gilbert, 2000). Apabila seseorang mengalami stres berkepanjangan dan tidak mendapatkan penanganan tepat, maka akan menimbulkan depresi. Depresi dapat mengakibatkan keinginan dan upaya bunuh diri, mengurung diri, gangguan tidur, gangguan makan, bahkan menolak beraktivitas secara individu maupun sosial (Meyer, 2002). Berangkat dari akibat yang ditimbulkan depresi yang dialami individu, maka depresi dianggap merugikan dan menghambat keberhasilan, baik secara kognitif maupun sosial, sehingga diperlukan model intervensi yang tepat untuk membantu seseorang keluar dari situasi depresi.

Depresi tidak terjadi secara tiba-tiba, namun depresi merupakan suatu proses, adanya gangguan yang terjadi karena adanya berbagai kejadian negatif sebelumnya yang menyebabkan seseorang merasa tertekan dan merasa kurang menyenangkan yang bertumpuk dan tidak terselesaikan. Adapun beberapa penyebab timbulnya depresi, menurut Mash dan Wolfe (1999), adalah sebagai berikut: (1) mengalami situasi penuh dengan tekanan yang sulit diselesaikan; (2) kehilangan kontak dengan orang terdekat; (3) berfikir tentang hal-hal negatif pada dirinya; (4) tidak ada seorangpun yang dapat dipercaya; (5) tidak mempunyai kawan dekat; (6) berada di sekitar orang dengan gangguan depresi; (7) memiliki kecenderungan dalam keturunan; dan (8) adanya perubahan kemikal pada otaknya.

Menurut Noelen dan Hoeksama (2004), penyebab seseorang mengalami gangguan depresi adalah karena faktor internal dan eksternal individu. Namun, secara teoritis dapat ditinjau dari beberapa dimensi, yaitu: (1) perspektif kelekatan yang mengatakan bahwa adanya hubungan yang signifikan antara terjadinya kelekatan yang tidak aman dengan kondisi depresif seseorang; (2) perspektif kognitif yang mengatakan bahwa adanya hubungan yang sangat signifikan antara skema negatif dari kognitif seseorang dengan kondisi perasaan depresif.

Dalam konteks interpersonal (pengaruh keluarga), depresi disebabkan oleh adanya : (1) kondisi stres yang akut atau kronis; (2) kurangnya dukungan sosial dalam relasional; (3) keluarga yang malang / sengsara; (4) adanya konflik antar orang tua; (5) orang tua yang mengalami depresi; dan (6) kehilangan orang tua / pengasuh. Sementara dari konteks interpersonal (hubungan teman sebaya) bahwa anak-anak yang mengalami kekurangan keterampilan sosial akan menglami depresi. Misalnya, kekurangan dukungan sosial dari teman sebaya, kurangnya kompetensi sosial, merasa kesepian, dan kurang memiliki keterampilan dalam problem solving.

Berdasarkan penjelasan di atas dapat disimpulkan bahwa beberapa faktor yang ditengarai sebagai penyebab gangguan depresi terdapat tiga sumber, yaitu : (1) adanya pemikiran otomatis yang negatif pada diri sendiri dan orang lain dan lingkungannya; (2) adanya behavioral yang dipelajari, yaitu adanya reaksi negatif atas kejadian yang tidak menyenangkan; dan (3) adanya hubungan interpersonal yang kurang baik dengan orang lain dan lingkungannya.

\section{METODE PENELITIAN}

Penelitian ini merupakan penelitian survei, maka data yang akan diperoleh disajikan dalam bentuk deskriptif kuantitatif dan kualitatif. Adapun variabel penelitian ini kondisi psikologis remaja dengan gangguan depresi. Dimensi yang diungkap adalah gangguan depresi, kebutuhan psikologis, 
pola asuh, model kepribadian, pola penyelesaian masalah, dukungan dan motivasi serta dorongan yang diperlukan.

Populasi penelitian ini adalah remaja dengan gangguan depresi kategori sedang dan tinggi yang berstatus pelajar kelas XI SMA Negeri dan Swasta di Surabaya. Dengan demikian, subjek penelitian ditetapkan berdasarkan teknik purposive sampling, yaitu penetapan subjek penelitian sesuai dengan tujuan penelitiannya.

Data penelitian diperoleh melalui metode observasi, dan kuesioner terbuka. Alat ukur yang digunakan adalah Alat ukur depresi yang digunakan adalah BDI (Back Depression Inventory). Alat ukur tersebut telah diujicobakan dan menunjukkan kualifikasi yang baik. Data yang diperoleh dalam penelitian ini akan ditampilkan secara deskriptif kualitatif dan kuantitatif dalam bentuk diagram, grafik, tabel, dan dianalisis secara kualitatif berupa deskriptif eksplanatif.

\section{HASIL PENELITIAN}

Tujuan penelitian ini adalah untuk mengidentifikasikan kebutuhan psikologis dan mengembangkan model intervensi bagi remaja dengan gangguan depresi. Namun sebelum ditinjau lebih jauh terhadap kebutuhan psikologis, peneliti akan menyajikan data hasil penelitian dalam bentuk gambaran dan persentase remaja dengan gangguan depresi di Surabaya.

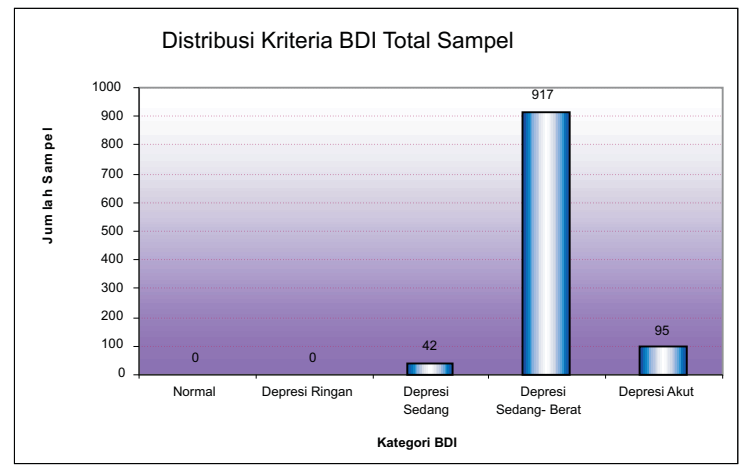

Gambar 1. Peta Gangguan Depresi pada Sampel Penelitian

Berdasarkan gambar di atas dapat dilihat bahwa hasil penelitian menunjukkan remaja dengan gangguan depresi pada kategori normal (tidak depresi) dan depresi ringan tidak ada (nol). Sedangkan subjek dengan depresi sedang sebanyak 42 orang $(4.022 \%)$. Jumlah remaja dengan depresi berat sebanyak 917 orang $(87,8 \%)$ dan remaja dengan depresi akut sejumlah 95 orang $(9.09 \%)$.
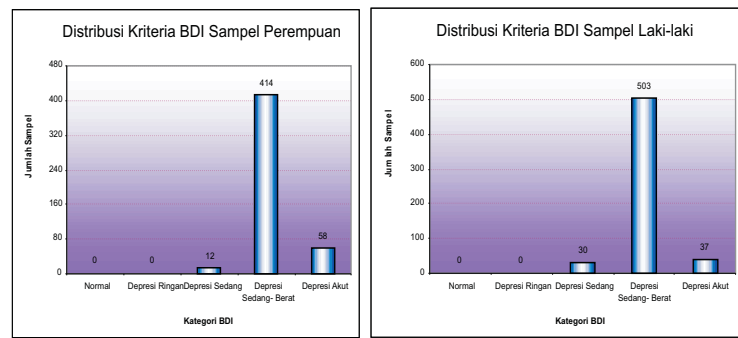

Gambar 2. Peta Gangguan Depresi Berdasarkan Jenis Kelami

Grafik di atas menunjukkan penyebaran remaja dengan gangguan depresi pada jenis kelamin perempuan. Grafik tersebut menunjukkan bahwa tidak ada subjek yang tidak mengalami gangguan depresi sampai dengan kategori ringan, yaitu $0 \%$. Sedangkan jumlah subjek dengan gangguan depresi sedang sebanyak 12 Orang $(2,479 \%)$. Subjek dengan gangguan depresi berat sebanyak 414 Orang $(85,53 \%)$ dan subjek dengan gangguan depresi akut sebanyak 58 Orang $(11,98 \%)$. Grafik di atas juga menunjukkan bahwa remaja laki-laki yang mengalami depresi akut sebanyak 37 orang $(6,49 \%)$, sedangkan depresi dengan kategori berat sebanyak 503 Orang $(88,24 \%)$ dan depresi dengan kategori sedang sebanyak 30 Orang $(5,26 \%)$ dan untuk kategori ringan tidak ada (o\%)

Analisis terhadap data yang dihimpun melalui kuesioner terbuka dan wawancara sebagian dari subjek penelitian yang mengalami gangguan depresi akut adalah bahwa faktor yang dianggap sebagai penyebab gangguan depresi yang dialami oleh remaja di Surabaya adalah faktor pendidikan, hubungan dengan orang-orang dekat, kehilangan orang dekat, dukungan sosial dalam pola pengasuhan dan faktor keuangan serta pola hidup yang kurang sesuai dengan kemampuan.

Selain faktor yang tersebut sebagai pemicu atau penyebab terbesar timbulnya gangguan depresi, sebagian besar dari subjek memerlukan teman untuk bercerita tentang masalah yang dirasakannya. Adapun cerita kepada teman ini lebih banyak untuk 
memperoleh dukungan emosional dengan mendengarkan ceritanya serta mendapatkan dukungan sosial dalam bentuk didengarkan, diperhatikan dan disayangi serta dipahami. Namun sebagian kecil dari mereka yang memerlukan teman untuk diskusi serta membicarakan permasalahan untuk mencari jalan keluar. Berdasarkan data tersebut dapatlah disimpulkan bahwa kebutuhan kognitif subjek masih kurang untuk mendapatkan solusi berdasarkan hasil diskusi dengan temannya. Selain masalah kognitif kita juga memperoleh gambaran bahwa subjek yang mengalami gangguan depresi masih banyak yang memerlukan kehadiran orang lain untuk bercerita, berbicara dan berkeluh kesah. Sedangkan yang ingin menyendiri masih dalam jumlah yang jauh lebih sedikit. Dari gambartan tersebut dapatlah dilihat bahwa kepribadian subjek lebih banyak yang terbuka dan menerima kehadiran orang lain.

Hasil penelitian selanjutnya adalah bahwa sebagian besar subjek penelitian juga memerlukan dukungan sosial dan emosional dari teman dan orang tua atau keluarga untuk mendapatkan dukungan, perhatian dan kasih sayang serta pemahaman atas masalah yang sedang dialaminya.

Penelitian ini juga mendapatkan hasil bahwa masih banyak subjek penelitian yang mengambil tindakan menyendiri, mengurung diri di kamar atau berada di tempat yang jauh dari keramaian dan kehadiran orang lain untuk menyelesaikan masalahnya. Sedangkan sebagian kecil ingin menumbuhkan semangat dan motivasinya sendiri, serta ada yang mencari teman untuk menghibur dengan rekreasi dan bermain.

Hal lain yang menjadi hasil penelitian ini adalah dukungan yang diperlukan oleh subjek dengan gangguan depresi adalah sebagian besar dalam bentuk saran dan semangat dari orang lain.

Orang lain yang banyak diperlukan subjek yang mengalami gangguan depresi untuk memberikan dukungan dalam menyelesaikan masalah tersebut adalah sebagian besar orang tua, kemudian teman dan dalam jumlah yang kecil mereka memerlukan keluarga selain orang tua. Tempat bercerita atau sharing berbeda dengan tempat mencari solusi. Sebagian besar remaja ingin sharing dengan teman (pada bagian sebelumnya) namun ketika mereka memrlukan jalan keluar, kebanyakan mereka lari ke pada orang tua. Orang tua adalah orang pertama yang dianggap dapat memahami, melindungi, menyayangi dan memberikan pengalaman kepada anak, sebagian waktu anak-anak juga dihabiskan dengan orang tua dan keluarga lain.

Simptom yang dirasakan oleh remaja dengan gangguan depresi berdasarkan hasil penelitian yang diambil melalui angket terbuka pada remaja dengan gangguan depresi adalah adanya gangguan konsentrai, gangguan mood dan emosi, gangguan tidur, gangguan nafsu makan, gangguan minat sosial, dan keinginan menarik diri dari lingkungan.

\section{PEMBAHASAN}

Depresi merupakan suatu gangguan psikologis yang disebabkan oleh adanya kejadian negatif yang sering dialami oleh individu dalam hidupnya (Beck, 1967). Kejadian negatif yang sering membuat remaja mengalami depresi adalah kegagalan, kehilangan orang terdekat, hubungan sosial dengan orang lain yang kurang menyenangkan (Mash dan Wolfe, 1999). Kegagalan yang mungkin dialami oleh remaja adalah ketidak mampuannya dalam mencapai prestasi tertinggi dalam hidupnya, tidak mampu bersaing dalam hal materi dan status sosial yang diinginkan serta kegagalan membangun relasi dengan teman sesama atau berlainan jenis. Sedangkan relasi dan interaksi sosial yang juga menyebabkan depresi adalah hubungan yang buruk dengan anggota keluarga termasuk dengan orang tua, saudara kandung teman, sahabat dan teman dekat atau pacar. Selain itu adanya perbedaan persepsi terhadap pola asuh serta perbedaan keinginan dan harapan dalam mengasuh anak yang akan menimbulkan ketidak harmonisan dalam hubungan.

Perlakuan yang kurang tepat dari orang tua dan lingkungan juga menyebabkan situasi yang kurang menyenangkan, sehingga menimbulkan beban dan kekurangharmonisan bagi individu dalam hubungannya dengan orang lain. Perasaan 
tidak nyaman dan kurang menyenangkan ini akan semakin menjadi persoalan serius ketika individu memiliki persepsi negatif terhadap dirinya, orang lain dan lingkungannya. Situasi seperti inilah yang dinyatakan oleh Beck (1967) sebagai penyebab munculnya gangguan depresi pada seseorang yang dikenal dengan teori depresi “tiga penjuru kognitif negatif". Berdasarkan hasil penelitian ini diperoleh informasi bahwa faktor penyebabnya adalah faktor tuntutan dan beban pendidikan, hubungan dengan orang-orang dekat, kehilangan orang dekat, dukungan sosial dalam pola pengasuhan dan faktor keuangan serta pola hidup yang kurang sesuai dengan kemampuan.

Sebagimana dijelaskan dalam kajian teoritis, bahwa faktor penyebab gangguan depresi adalah adanya beban terlalu berat, adanya peristiwa negatif dari lingkungan, persepsi negatif terhadap diri sendiri, orang lain dan lingkungan, kurangnya dukungan sosial, hubungan baik dan harmonis dari orang lain disekitarnya, kehilangan orangorang terdekat, mendapatkan cara pengasuhan yang kurang sesuai dengan harapan, beban kehidupan secara sosial dan ekonomi serta tuntutan yang berat dari lingkungan (Mash \& Wolfe, 1999).

Beberapa faktor yang dijelaskan di atas dianggap sebagai pemicu timbulnya gangguan depresi pada remaja. Sebagaimana kita ketahui untuk dapat bertahan hidup di kota metropolis seperti Surabaya, masyarakat memang dituntut untuk memiliki kemampuan dan daya tahan yang cukup kuat agar tetap dapat bertahan hidup. Sebab Surabaya sebagai kota besar kedua di Indonesia memiliki berbagai macam fasilitas yang sangat beraragam. Untuk bisa memperoleh dan menikmati fasilitas tersebut masyarakat perlu berbagai usaha dan kekuatan untuk dapat menikmatinya. Fasilitas yang dimaksud di sini mulai dari bidang pendidikan, kesehatan, hiburan, keagamaan, olahraga, transportasi dan lainlain. Masyarakat dituntut sedemikian berat untuk dapat memperebutkan fasilitas yang memadai sesuai dengan keinginan dan harapan.

Sebagaimana hasil temuan penelitian bahwa remaja yang sedang mengalami gangguan depresi akan meminta bantuan untuk berbagi dan menyelesaikan masalahnya kepada teman, saudara, dan orang tua. Kebiasaan ini dapat dipahami sebab usia remaja adalah usia yang dekat dengan peer group, individu mencari dan mendapatkan identitas dirinya melalui peer group, sehingga banyak kegiatan yang dilakukannya bersama dengan teman sekelompoknya, baik yang sejenis maupun yang berlainan jenis. Oleh sebab itu banyak waktu yang digunakan untuk berkumpul bersama peer group. Selain peer group, remaja juga merasa lebih dekat dengan orang tua atau saudara. Oleh sebab itu tidaklah heran apabila remaja mengalami masalah ia akan lari dan mengeluh kepada orang tua dan saudara. Sebagai orang yang dekat dengan remaja, teman, orang tua dan saudara akan memberikan dukungan sosial dan emosional kepada remaja yang sedang mengalami masalah. Hal ini akan membantu remaja untuk dapat mengatasi dan menyelesaikan masalah secara perlahan-lahan. Sebagaimana pendapat Mash dan Wolfe (1999) mengatakan bahwa salah satu dari bentuk terapi yang dapat diberikan untuk membantu remaja yang mengalami gangguan depresi adalah dengan memberikan terapi sosial dan interpersonal. Bentuk terapi semacam ini akan dapat membantu memberikan support dan kedekatan serta kehangatan bagi remaja agar mampu menerima dan memahami apa yang sedang terjadi pada dirinya serta menguatkan mentalnya untuk dapat menyelesaikan permasalahan tersebut.

Hasil penelitian ini juga menunjukkan bahwa upaya yang dilakukan oleh remaja yang mengalami gangguan depresi untuk menyelesaikan masalahnya adalah dengan menyendiri, mencari hiburan, mencari kegiatan lain seperti mencari teman untuk curhat, dan menceritakan kepada orang tua. Kegiatan seperti ini tidak lepas dari usaha remaja sesuai dengan kemampuan, jenis kepribadian, dan kebiasaan yang dilakukan untuk sejenak melupakan masalah yang sedang dialami oleh remaja itu. Adapun beberapa jenis kegiatan yang dipilih oleh remaj untuk menghibur diri dan 
menyelesaikan permasalahan yang dialaminya. Kegiatan yang sifatnya rekreatif dianggap mampu membantu untuk menghilangkan perasaan yang kurang menyenangkan, kesedihan, kemarahan dan ketidaknyamanan yang dirasakan.

Remaja masih memilih teman atau sahabat sebagai orang pertama yang dilibatkan untuk membantu menyelesaikan permasalahan yang dialaminya. Temuan ini menunjukkan betapa kurang dekatnya hubungan antara anak dan orang tua, sehingga remaja yang mengalami masalahpun tetap lari kepada teman, sahabat atau pacar sebagai pilihan pertama untuk mendengarkan cerita, sharing dan keluahannya. Sebagaimana dikatakan oleh Hurlock (1981) bahawa usia remaja adalah usia dimana seseorang mulai keluar dari lingkungan keluarga, mencari teman di luar rumah, dilingkungan dan masyarakat lain, baik terhadap teman sejenis maupun berlawanan jenis.

Sebagaimana gangguan depresi secara umum, simptom depresi yang dirasakan oleh remaja yang sedang mengalami gangguan depresi adalah sering melamun, kurang konsentrasi, mudah marah, mudah tersinggung, menurunnya selera makan, gangguan tidur, malas melakukan kegiatan, malas belajar dan mudah lelah. Hal ini juga sudah ditegaskan oleh para ahli khususnya gangguan emosi atau depresi, maka simptom yang muncul sebagaimana tersebut diatas merupakan tanda yang umum dialami oleh orang dengan gangguan depresi.

\section{Simpulan}

\section{SIMPULAN DAN SARAN}

1. Jumlah remaja baik laki-laki maupun perempuan yang tidak mengalami gangguan depresi dan yang mengalami gangguan depresi ringan sebanyak nul.

2. Jumlah remaja baik laki-laki maupun perempuan dengan gangguan depresi dalam kategori berat lebih banyak dari pada kategori sedang dan akut.

3. Jumlah remaja perempuan yang mengalami gangguan depresi akut lebih banyak dari pada laki-laki.

4. Subjek dengan gangguan depresi kurang memerlukan dukungan dan bantuan dalam bentuk kognitif, namun mereka lebih banyak memerlukan bantuan dan dukungan dalam bentuk afektif dan sosial.

5. Orang yang banyak dibutuhkan untuk dapat memberikan dukungan afektif dan sosial bagi remaja dengan gangguan depresi adalah teman dan orang tua, kemudian keluarga lain.

6. Bentuk dukungan afektif yang banyak diperlukan oleh remaja dengan gangguan depresi adalah kesediaan mendengarkan cerita, tempat curhat dan berkeluh kesah. Namun sebagian kecil membutuhkan hiburan dan kebersamaan.

7. Tindakan fisik yang banyak dilakukan oleh remaja dengan gangguan depresi pada awal timbulnya gangguan adalah dengan menyendiri, mengurung diri, berada di tempat sepi. Setelah itu mereka perlu mencari teman, hiburan, dan semangat atau saran.

8. Sebagian besar dari remaja yang mengalami gangguan depresi merasa mendapatkan pola asuh dan penidikan yang otoriter, kemudian dekratis dan permisif.

9. Sedangkan pola asuh dan pendidikan yang diharapkan adalah yang demokratik, sebagian kecil saja ingin mendapatkan pola asuh otoriter dan demokratik.

10. Bentuk dukungan dan bantuan yang diperlukan dari orang lain (teman dan Orang tua) adalah dalam bentuk saran, semangat, motivasi, dan dorongan. Hanya sebagian kecil yang memerlukan bantuan kasih sayang dan materi.

11. Jalan keluar yang banyak ditempuh oleh remaja dengan gangguan depresi adalah menyemangati diri sendiri, memotivasi diri sendiri dan dorongan dari orang lain.

\section{Saran}

1. Bagi remaja perlu adanya komunikasi terbuka dengan orang tua, teman atau sahabat untuk mencurahkan perasaan, menyelesaikan masalah, dan mendiskusikan jalan keluarnya.

2. Bagi orang tua perlu untuk mengenal persepsi anak terhadap pola asuh yang diberikan, dan apabila terdapat ketidak 
sesuaian dengan harapan anak, maka orang tua perlu berusaha untuk merubah sesuai dengan harapan.

3. Bagi orang tua yang mengetahui adanya perubahan sikap menjadi pendiam, pemurung, mengurung diri dan menyendiri dari anaknya, maka perlu berbicara dan membicarakan dengan anak atas permasalahan yang dihadapi serta mencari solusi dan nasehat dari para ahli.

\section{DAFTAR PUSTAKA}

Beck, A.T. (1967). Depression, Clinical, Experimental and Theoritical Aspects. USA: Harper and Row Publisher.

Beck, A.T. (1967). Hand Book Of Depression. USA: Harper and Row Publisher.

Bum, D.D. (2006). Depression for Aoloscence, New York: McGraw Hill Inc.
Gilbert, H.B. (2000). Psycho Pathology. New York: McGraw Hill, Inc.

Hurlock, E.B. (1981). Child Developmental Psychology. New York: McGraw Hill. Inc.

Mash, E.J. \& Wolfe, DA.(1999). Abnormal Child Psychology. USA: Wadsworth publishing Company. A Division of International Thomson Publishing Inc.

Meyer. G.L. (2002). Abnormal Psychology. New York: Mc.Graw Hill.Inc.

Mulayadi, S. (2006). Stres pada anak. Simposium Nasional Fakultas Pasca Sarjana UMS. Solo: Fakultas Pasca Sarjana UMS.

Noelen.S \& Hoeksema, 2004.Abnormal Psychology. $3^{\text {rd }}$ Ed. Boston: Higher Education.McGraw Hill. University OfMichigan. 